\title{
Application of Online Multimedia Courseware in College English Teaching Based on Constructivism Theory
}

\author{
Zhenying Li \\ School of Foreign Languages, Beihai College of Beijing University of Aeronautics and Astronautics \\ 88 Silver Beach Boulevard, Beihai 536000, China \\ E-mail: zhenyingli@126.com
}

Received: November 14, 2011

Accepted: December 16, 2011

Published: March 1, 2012

doi:10.5539/elt.v5n3p197

URL: http://dx.doi.org/10.5539/elt.v5n3p197

\begin{abstract}
Based on Constructivism Theory, this paper aims to investigate the application of online multimedia courseware to college English teaching. By making experiments and students' feedback, some experience has been accumulated, and some problems are discovered and certain revelations are acquired as well in English teaching practice, which pave the way for further application of the multimedia internet technology to English teaching.
\end{abstract}

Keywords: Online multimedia courseware, Constructivism, Autonomic learning, College English teaching

\section{Introduction}

The information technology level has been improved in a high speed since human being entered $21^{\text {st }}$ century. The technologies of communication, internet and multimedia have penetrated all aspects of education. Working, studying, thinking and communicating styles of human being have been influenced by Infobahn in a striking speed. The mode of traditional teaching centered on classroom, textbook and teacher can't adapt to the demand of the development of information times. A lot of teachers from colleges and universities have increasingly realized the importance of obtaining the information from internet. And with great concentration, they are studying how to use the internet source to change the methods of learning and teaching (Johnson, 2001). They are committing themselves to make network courseware and construct modern teaching mode of college English based on constructivism theory. Owing to its advantages of affording interactive learning environment of interface amity and visualized and intuitionistic characteristics, multimedia and internet technology, the new technology and method has been increasingly applied to the teaching actively in order to develop online multimedia courseware and realize online teaching.

At present, however, the situation of our college obviously trails the other colleges in the construction of online multimedia subjects. There are not still relatively systematic and distinctive online teaching course wares or online courses adapting to the level of our college now, hence, it restricts the teaching means in diversification. The study is to do the primary attempt in online teaching and tries to construct the mode of autonomic learning through developing online multimedia courseware and enriching the contents of internet courseware on the campus net of our college.

\section{Theoretical Background}

Formalization of the theory of constructivism is generally attributed to Jean Piaget (1950), who articulated mechanisms by which knowledge is internalized by learners. It is important to note that constructivism is not a particular pedagogy. In fact, constructivism is a theory describing how learning happens, regardless of whether learners are using their experiences to understand a lecture or following the instructions for building a model airplane. In both cases, the theory of constructivism suggests that learners construct knowledge out of their experiences. It says that people construct their own understanding and knowledge of the world, through experiencing things and reflecting on those experiences. When we encounter something new, we have to reconcile it with our previous ideas and experience, maybe changing what we believe, or discarding the new information as irrelevant. In any case, we are active creators of our own knowledge (Hedge, 2000). To do this, we must ask questions, explore, and assess what we know.

Nevertheless, constructivism is often connected with teaching methods that promote active learning, learning by doing. There are many critics of "learning by doing" as an instructional strategy (Tobias and Duffy, 2009). While there is much enthusiasm for Constructivism as a design strategy, according to Tobias and Duffy (2009) "... to us it would appear that constructivism remains more of a philosophical framework than a theory that either allows us to 
precisely describe instruction or prescribe design strategies (p.4)". This is unfortunate because there is quite a bit of promise to the educational philosophy behind constructivism, but constructivists seem to be having difficulties defining testable learning theories. In part this is due to Piaget's distrust of empirical methods and reliance upon the clinical method.

One the basis of constructivism, teachers should encourage students to constantly assess how the activity is helping them gain understanding under the environment of online multimedia courseware. By questioning themselves and their strategies, students ideally become "expert learners." This gives them ever-broadening tools to keep learning. With well-planned online multimedia courseware, the students learn how to learn. In the process of online multimedia courseware's design and multimedia teaching, teachers should pay more attention to students' preexisting knowledge (Skeha, 1998). As scientific guides, they should instruct students to construct new knowledge and learning environment. I hope to provide a mass of intelligible language input involving the knowledge learnt and improve the speed and efficiency of language acquisition through the online multimedia courseware and subjects.

This study expects to reinforce students' independence in study and offer the platform of autonomic learning for them, meanwhile, promote the textbook to have the characteristics of vitality and individuation through online multimedia teaching and learning. It enhances the quantity of information input and arouses students' enthusiasm in study as well (Ur, 1998). In the study, I encourage students to attend the study and research in order to develop their creativity and realize self-feedback. Meanwhile, the classroom teaching activity can be extended.

\section{Process of Studying the Subject}

The subject is instructed by constructivism theory and based on the contents of current college English books (New Horizon College English Book 1 \& Book 2). It involves several topics, for example, science and technology, tourism, P.E., festival, diet etc. The online multimedia courseware are made up of correlative texts, audio and visual materials from the abundant information resource on internet and are shown to students through computer multimedia (visual, audio and cartoon), pictures, texts etc., the classroom main components. The knowledge of textbook, including the explanation of key points and grammar items and the design of interactive practice is embodied during the process of making online multimedia courseware (Jianlin Chen, 2000). Moreover, there are many aspects being emphasized, such as, to highlight the introduction of background knowledge, to pay attention to correlative knowledge of links and reading, to expand students' knowledge, to mobilize students' study interest as much as possible, to help students understand and solve difficulties and emphases in study and construct the mode of autonomic learning on the basis of the contents of textbook (Ellis, 1985). And through questionnaires, to collect the ideas and recommendations from students' feedback on the use of the courseware series and to form a study report exploring ways to further improve online multimedia courseware construction and construct student-centered teaching mode.

\section{Results of the Questionnaire}

\subsection{Statistics of the Data}

From the statistics of data: table 1(Shares of questionnaires: 200, callback ratio: 100\%).

$143(71.5 \%)$ students consider that multimedia courseware can increase the input quantity of target language; 57 $(28.5 \%)$ consider that it can not.

$136(68 \%)$ students consider that multimedia teaching can improve their study interest; 64 (32\%) consider that their study interest has not been improved.

157 (78.5\%) consider that multimedia teaching can improve their innovative sense; 43 (21.5\%) students consider that it can not.

$121(60.5 \%)$ students consider that multimedia teaching can develop their abilities of exploring learning; 79 (39.5\%) consider that it can not.

92 (46\%) students consider that there is a good effect to use multimedia courseware to have lesson; 83 (41.5\%) students consider that the effect is common; and $25(12.5 \%)$ students consider that the effect is not good.

89 (44.5\%) consider that the aim of using online multimedia courseware continuously is consolidate the classroom knowledge after class; 135 (67.5\%) students consider that its aim is reading the other correlative materials in internet subjects; 126 (63\%) students consider that its aim is to look for more correlative knowledge actively; 74 (37) students consider that its aim is to learn analyze and sum up the materials and to improve the capacity of handling information; and $28(14 \%)$ students have other aims.

$68(34 \%)$ students consider that classroom teaching and learning to use multimedia courseware and internet courseware should focus on developing students' memory abilities; $126(63 \%)$ students consider that it should focus 
on developing students' analysis abilities; 87 (43.5\%) consider that it should focus on developing students' imagination abilities; 117 (58.5\%) students consider that it should focus on developing students' creation abilities; $39(19.5 \%)$ students consider that it should focus on developing students' other abilities.

Through multimedia teaching, 58 (29\%) students discover that they have trained and improved their abilities to new lessons in autonomic learning; $122(61 \%)$ students discover that they have trained and improved their abilities in searching, processing, dealing with and communicating information; 78 (39\%) students discover that they have trained and improved their abilities in analyzing, handling and solving problems; 89 (44.5\%) students discover that they have trained and improved their abilities in autonomic learning; 45 (22.5\%) students discover that they have trained and improved their abilities in creation; 18 (9\%) students discover that they have trained and improved their abilities in other aspects.

\subsection{Research Results of Open-ended Questions}

\subsubsection{Your Aim to Surf on the Internet is ...}

The majority of students are searching study materials; some are chatting, finishing their assignments, browsing the news, downloading English news; listening to English; receiving and sending emails; entertainments (listening songs, playing games and seeing films).

4.2.2 Do You Want to Have a Special Education Site on Classroom Teaching or Electronic Database? What Are the Main Contents about to Want?

Most students gave positive answers, a few thought that was indifferent. Most students hope that there were some materials integrating entertainment into learning information relating to the contents of texts; correlative contents (including key syntax analysis, teaching program, language points analysis, exercises, simulation test, background knowledge, text recordings etc.); some relevant background knowledge (the original English film and English television programs, the introduction of Britain and America on national human geography), vocabulary knowledge (the word classification), audio-visual materials and the corresponding practice; CET-4 examination exercises and some analysis better including examination papers at all levels; the introduction of study methods; all kinds of extra-curricular knowledge (current events, philosophy of life, the situation of education in current society etc.), the excellent teachers' lessons; the exercise database providing answers and the explanations and sentences; the information of some other colleges in learning and examination.

4.2.3 Your Opinions on the Advantages of Current Multimedia Courseware and Online Courses in the English Teaching of Grade One Are ...

The majority consider that it is visualized and lively that multimedia courseware and internet courses in the English teaching of grade one. There are a lot of advantages, for instance, a large number of information, better conclusion, good layout, having close connection with textbook, listing the difficulties and key points and letting students review and preview on purpose, adding substantial supplementary materials to expand the knowledge, impressing students through vision, attracting students' attention, good learning effect; helping to improve students reading ability, better for students to practice in time and train the students' autonomic learning ability; making the classroom atmosphere more active, comparatively lively and interesting, making the classroom atmosphere active, saving the time for teachers to write on the blackboard.

4.2.4 Your Opinions on the Disadvantages of at Present Are Multimedia Courseware and Internet Courses in the English Teaching of Grade One Are ...

The disadvantages are: Designed too simple and not enough handsome, less innovation; tedious texts, less audio materials; less pictures, not enough screen images, urgent to develop the contents; less explanation and profound analysis; not benefit students to master the systematic knowledge; lack of interactive activities between and students, lack of audio-visual materials and correlative exercises; some boring contents, lack of interesting. Limited hardware facilities, sometimes equipments carried out not so smoothly Resulting in a waste of time; used less multimedia courseware and internet courses in teaching; some students mentioned that the keys to the exercises were shown too fast and they hoped to master the contents of texts by themselves, to add the recordings of texts and words practice; too active classroom, not conducive to think calmly.

\section{Conclusion and Revelation}

From the results above, I found some problems and got some revelations.

\subsection{The Usage of Online multimedia Courseware Brings Many Advantages to Teaching}

According to statistics, the majority of students consider that the usage of multimedia teaching has a good effect. There are some characteristics, for example, audio images, vivid and lively, relaxed and happy learning environment, 
to change hard learning to happy learning, plenty of teaching information, across time and space, rich extra-curricular knowledge, benefiting to expand students' knowledge. Furthermore, most students like the usage of multimedia teaching in classroom because they believe that there are many advantages in this kind of class, for example, vivid and lively, integrating teaching into entertainment, relaxed and good classroom atmosphere, beneficial to students to stimulate their thought, character cultivation, in favor of the creation of students in the classroom teaching environment, good study results. Therefore, there are about 50 percent of students in the class who like to continue to use the network-based multimedia courseware to consolidate classroom knowledge or read other relevant materials in internet subjects. It is the matter for congratulation that there are more than 60 percent of students who seek more correlative knowledge to improve their abilities of analyzing, summarizing materials and processing information through online multimedia courseware and internet courses.

In the aspect of training students' comprehensive capacities (Dingfang Shu, and Zhixiang Zhuang, 1996), there are nearly 70 percent of students believe that we should focus on developing students' capabilities of analysis and creation through by usage of online multimedia courseware and internet courses in classroom teaching and extra-curricular learning. Meanwhile, there are nearly 67 percent of students find their capabilities trained and improved in searching for information, processing information, dealing with information and communicating information through multimedia teaching.

\subsection{The Necessity of Guidance for Students'Surfing on the Internet}

Through the survey, we find that about 90 percent of the students spend 1-5 hours per week in surfing on the internet in general. There are different purposes to students on the internet: searching learning materials, chatting, writing assignments, accessing to all kinds of knowledge, including reading news, sending and receiving e-mails, entertainment (listening to the music, playing games, watching movies) etc. In fact, playing games and chatting have occupied much time online of students. Moreover, because the internet also conveys all kinds of contents, the negative impact on the students should not be neglected. Therefore, teachers should provide more guidance and help for students so that students can consciously avoid undesirable contents on the internet. Meanwhile, let students know the internet can be not only used to exchange, browse and entertain but the more important thing is that we should make good use of it to collect information, research and explore.

\subsection{Students' Positive Attitude towards the Subject}

From the statistics, there are more than 50 percent of students believe that there is a good effect through the usage of multimedia internet courseware. There are more than 50 percent of students who like multimedia teaching and consider it can develop their exploring learning abilities through multimedia teaching and learning. And there are nearly 70 percent of students who believe that multimedia teaching can increase their learning interest and promote autonomic learning enthusiasm. There are nearly 80 percent of students who consider that multimedia teaching can enhance students' innovation sense. There are nearly 70 percent of students who believe that it can increase the quantity of target language (English) input by the usage of multimedia courseware.

Most students consider that there are many advantages in the multimedia courseware and internet courses of college English teaching, grade one, such as, vivid, informative, systematic, strong summarization, good layout and more close teaching materials integration. It sets out the difficulties and key points, and it can make students review and preview on purpose. It can also add a lot of complementary materials to expand knowledge. It can impress students through their vision and draw students' attention. And there is a good effect on English teaching. It can help students improve their reading abilities and do the exercises in time. Moreover, it can cultivate students' autonomic learning and make classroom atmosphere actively.

\subsection{The Feedback of Students and Reflected Deficiency in Courseware}

Students put forward some suggestions: They expect that the multimedia internet courseware and course have the characteristics of perfect design, innovation, times and rich in contents (including pictures, visual and audio materials). Furthermore, there should be profound analysis of texts, materials supporting audio-visual, correlative exercises and English examination problems and learning methods. And at the same time, we should also compare all kinds of extracurricular knowledge (current events, philosophy of life, the situation of education in current society etc.); study and examination information from other colleges and universities; the interactive activities between teachers and students on the basis of internet.

There are some deficiencies in the courseware behind all students' expectations: (1) the computer network technology of teachers does not meet the demand of necessities of students; there are not sufficient video and audio software materials. Therefore, teachers should strive to improve the practice capabilities of computer network technology in spare time. (2) Because the hardware facilities are limited at our college and the equipment sometimes 
does not run smoothly, it results in a waste of time in teaching process. And the usage of multimedia internet courseware and course network is too little. Consequently we appeal to the college to improve the computer network equipment as soon as possible and let the internet teaching resources be really able to serve teaching and improve the quality of teaching.

\section{References}

Dinfang Shu, \& Zhixiang Zhuang. (1996). Modern English Teaching - Theory, Practice and approaches. Shanghai: Shanghai Foreign Language Education Press.

Ellis, R. (1985). Understanding Second Language Acquisition. Oxford: Oxford University Press.

Hedge, T. (2000). Teaching and Learning in the Language Classroom. Oxford: Oxford University Press.

Jianlin, Chen. (2000). The Organization and Management in Modern English Teaching. Shanghai: Shanghai Foreign Language Education Press.

Johnson, K. (2001). An Introduction to Foreign Language Learning and Teaching. London: Longman.

Piaget, J. (1950). The Psychology of Intelligence. New York: Routledge.

Skeha, P. A. (1998). Cognitive Approach to Language Learning. Oxford: Oxford University Press.

Tobias, S., \& Duffy, T. M., (2009). Constructivist instruction: Success or failure? New York: Taylor \& Francis.

Ur, P. A. (1996). Course in Language Teaching: Practice and Theory. Cambridge: CUP.

Table 1.

\begin{tabular}{|c|c|c|c|c|c|c|c|c|c|c|c|c|}
\hline Option & & A & & 3 & & C & & ) & & $E$ & & \\
\hline $\begin{array}{l}\text { Test } \\
\text { Question }\end{array}$ & ss & $\%$ & ss & $\%$ & ss & $\%$ & ss & $\%$ & ss & $\%$ & ss & $\%$ \\
\hline 1 & 143 & 71.5 & 57 & 28.5 & & & & & & & & \\
\hline 2 & 136 & 68 & 64 & 32 & & & & & & & & \\
\hline 3 & 157 & 78.5 & 43 & 21.5 & & & & & & & & \\
\hline 4 & 121 & 60.5 & 79 & 39.5 & & & & & & & & \\
\hline 5 & 92 & 46 & 83 & 41.5 & 25 & 12.5 & & & & & & \\
\hline 6 & 89 & 44.5 & 135 & 67.5 & 126 & 63 & 74 & 37 & 28 & 14 & & \\
\hline 7 & 68 & 34 & 126 & 63 & 87 & 43.5 & 117 & 58.5 & 39 & 19.5 & & \\
\hline 8 & 58 & 29 & 122 & 61 & 78 & 39 & 89 & 44.5 & 45 & 22.5 & 18 & 9 \\
\hline
\end{tabular}

